\title{
PENGGUNAAN PROBIOTIK DALAM BUDIDAYA TERNAK
}

\author{
Angga Permadi (1), Mubalikhoh Aqidatul Izza ${ }^{(2)}$, Kukuh Cahyo ${ }^{(3)}$, \\ Muhammad Al Kholif, ST., MT ${ }^{(4)}$ \\ ${ }^{(1)}$ Fakultas Ekonomi Universitas PGRI Adi Buana Surabaya \\ ${ }^{(2)}$ Fakultas Keguruan dan Ilmu Pendidikan Universitas PGRI Adi Buana Surabaya \\ ${ }^{(3)}$ Fakultas Matematika dan IPA Universitas PGRI Adi Buana Surabaya \\ ${ }^{(4)}$ Dosen Teknik Lingkungan Universitas PGRI Adi Buana Surabaya \\ Email : ${ }^{(4)}$ alkholif87@unipasby.ac.id
}

\begin{abstract}
ABSTRAK
Probiotik merupakan mikroorganisme tertentu yang ada dalam tubuh hewan dan akan menjamin pembentukan secara efektif organisme yang bermanfaat dalam tubuh inang (hewan) terutama sistem pencernaan karena mampu memperbaiki keseimbangan mikroflora usus. Probiotik mengandung bakteri menguntungkan yang dimasukkan kedalam pencernaan untuk mendominasi bakteri yang menimbulkan penyakit (patogen) menurun. Probiotik dapat mengandung satu atau beberapa jenis mikroorganisme yang serupa (strain). Berbentuk powder, tablet, padat berbentuk bulat (granula), serta seperti campuran beberapa bahan yang lembek (pasta). Probiotik bekerja dengan cara menekan populasi mikroba melalui kompetisi dengan memproduksi senyawa antimikroba atau melalui kompetisi nutrisi, merubah metabolisme mikrobial dengan meningkatkan atau menurunkan aktivitas enzim, serta menstimulasi imunitas melalui peningkatan kadar antibodi atau aktifitas sel besar yang mampu mencerna bakteri dan sisa sel dalam jumlah yang sangat besar (makrofag). Pemberian probiotik bertujuan untuk memperbaiki kondisi saluran pencernaan dengan menekan reaksi pembentukan racun dan metabolit yang bersifat bahan yang dapat mendorong atau menyebabkan kanker (karsinogenik), merangsang reaksi enzim yang dapat menetralisir senyawa beracun yang tertelan atau dihasilkan oleh saluran pencernaan, merangsang produksi enzim yang diperlukan untuk mencerna pakan dan memproduksi vitamin serta zat-zat yang tidak terpenuhi dalam pakan.Hasil yang diperoleh mulai digunakan setelah bau harum seperti tape keluar dari cairan dan terdapat gelembung gas. Probiotik yang diencerkan atau diperbanyak di sini dari jenis probiotik yang dicampurkan ke dalam pakan. Sebelum digunakan, probiotik baru ini juga perlu diencerkan dulu dengan air. Volume yang digunakan lebih banyak dari volume saat digunakan probiotik aslinya.Selain menambah volume cairan probiotik hingga dapat digunakan lebih lama, penambahan tetes pada probiotik ini juga dimaksudkan untuk meningkatkan aktivitas bakteri yang ada di dalamnya.
\end{abstract}

Kata kunci: Probiotik, mikroorganisme, hewan

\section{ABSTRACT}

Probiotics are certain microorganisms that exist in the animal's body and will guarantee the effective formation of beneficial organisms in the host's body (animals) especially the digestive system because it can improve the balance of the intestinal microflora. Probiotics contain beneficial bacteria that are inserted into the digestion to dominate bacteria that cause decreased (pathogenic) disease. Probiotics can contain one or several strains of similar microorganisms. Shaped powder, tablets, solid round shape (granules), and like a mixture of some soft ingredients (pasta). Biotics work by suppressing microbial populations through competition by producing antimicrobial compounds or through nutritional competition, changing microbial metabolism by increasing or decreasing enzyme activity and stimulates immunity through increased levels of antibodies or large cell activity that is capable of digesting bacteria and large amounts of cells (macrophages). Probiotics aim to improve the condition of the digestive tract by suppressing the reaction of the formation of toxins and metabolites that are ingredients that can encourage or cause cancer (carcinogenic), stimulate enzyme reactions that can neutralize toxic compounds that 
are ingested or produced by the digestive tract, stimulate the production of enzymes needed to digest food and produce vitamins and substances that are not fulfilled in feed. The results obtained begin to be used after a fragrant smell like tape comes out of the liquid and there is a gas bubble. Probiotics that are diluted or reproduced here are of the type of probiotics mixed into the feed. Before use, this new probiotic also needs to be diluted first with water. The volume used is more than the volume when the original probiotic is used. In addition to increasing the volume of probiotic liquid until it can be used longer, the addition of drops to the probiotic is also intended to increase the activity of bacteria in it.

Keywords: Probiotics, microorganisms, animals

\section{PENDAHULUAN}

Saat ini asupan makanan dan multivitamin yang diberikan pada hewan ternak menjadi faktor utama menjaga kesehatan hewan ternak. Pemberian makanan yang tidak higenis, tidak bergizi dapat menjadi ancaman penyakit bagi hewan ternak terkait. Sebab di dalam makanan yang di berikan bisa mengandung virus yang ditularkan oleh udara atau dari hewan lainnya. Pemberian makanan yang salah dapat mengakibatkan hewan ternak terserang penyakit karena terjadi aktivitas mikroorganisme dalam saluran pencernaan ternak bisa mengakibatkan banyak hal, pertama penurunan imunitas hewan yang mengakibatkan mudah terserang penyakit. Kedua terjadi ganggunan fungsi usus, penyakit radang yang mengakibatkan ternak terkena diare. Yang terkahir hewan bisa mengalami penurunan berat badan dan stress.

Dari fenomena hewan ternak yang terkena penyakit menunjukan bahwa pemberian multivitamin pada hewan ternak sangat diperlukan untuk menjaga kekebalan tubuh hewan agar tidak mudah terserang penyakit. Dampak akibat penggunaan antibiotik dalam pakan yaitu dapat menyebabkan resistensi bakteri pada manusia dan hewan, terutama jika mengandung antibiotik, akan tetapi dengan alasan masalah resistensi, mulai 1 Januari 2006 Uni Eropa memutuskan untuk melarang penggunaan antibiotik sebagai pakan imbuhan (SIMON, 2005).Sehingga solusi terbaik untuk mengatasi imunitas hewan ternak dan menghindari dampak negative dari pemberian antibiotic dengan dengan mengkonsumsi miroorgaisme hidup yang menguntung kanusus (probiotik), komponen non cerna (prebiotik) dan kombinasi probiotik dan prebiotik (sinbiotik).

Oleh sebab itu peternakan di Desa Bening dapat memperbaiki kesehatan ternak mereka dengan menambahkan probiotik sebagai tambahan pakan ternak. Dengan penambahan probiotik hewan menjadi lebih kebal terhadap bakteri-bakteri dan virus yang menggangu pencernaan mereka. Sehingga sistem kesehatan ternak lebih kebal terhadap penyakit jika dibandingkan dengan ternak yang tidak diberi pakan imbuhan probiotik Desa Bening terletak di Kecamatan Gondang Kabupaten Mojokerto dengan mata pencarian sebagai petani dan peternak hewan. Namun para peternak hewan di desa Bening hanya mengandalkan pakan tradisional. Maka dari itu, kami mahasiswa KKN-PPM menerapkan kepada masyarakat untuk membuat probiotik sebagai campuran pakan terak hewan yang mampu menambah miklofora dalam saluran cerna serta meningkatkan laju pertumbuhan pada hewan ternak.

Probiotik adalah istilah yang digunakan pada mikroorganisme hidup yang dapat memberikan efek baik atau kesehatan pada organisme lain/inangnya. Karakteristik probiotik yang efektif adalah dapat dikemas bentuk hidup dalam skala industri, stabil dan hidup pada kurun waktu penyimpanan lama dan kondisi lapangan, bisa bertahan hidup di dalam usus dan menguntungkan bagi peternak. Kebanyakan bakteri probiotik berasal dari kelompok bakteri asam laktat (BAL) dan diantaranya Lactobacillus dan bifidokbateria memiiki peran yang signifikan dalam menjaga ekosistem pencernaan dan 
menstimulasi sisem imun inang (Kompiang, 2009).

Probiotik menciptakan keseimbangan mikroflora dalam saluran pencernaan sehingga menciptakan kondisi yang optimum untuk pencernaan pakan dan meningkatkan efisiensi konversi pakan sehingga memudahkan proses penyerapan zat nutrisi ternak, meningkatkan kesehatan ternak, memperpendek jarak beranak, mempercepat pertumbuhan, menurunkan kematian pedet, dan memproteksi dari penyakit patogen tertentu sehingga dapat meningkatkan produksi susu atau daging juga dapat digunakan untuk ke unggulan ikan lele adalah pertumbuhan ikan cepat dari lele varian lainnya, FCR rendah, lebih tahan terhadap strees dan penyakit serta memiliki sintasan yang tinggi.

Berdasarkan penjelasan di atas maka pembuatan artikel ini bertujuan agar masyarakat menyadari bahwa pemanfaatan probiotik merupakan sumber bahan paka yag dapat diberikan kepada ternak hewan dan ikan sehingga produktivitas hewan ternak dapat ditingkatkan.

Pemerintah Indonesia, tanggal 11 Juni 2005 merancang Program Revitalisasi Pertanian, Perikanan dan Kehutanan (RPPK). Hal ini ditindak lanjuti oleh Direktorat Jendral Perikanan Budidaya dengan menetapkan 120 komoditas unggulan karena mempunyai potensi besar untuk ekspor, yaitu: udang, rumput laut, ikan lele (dumbo), ikan kerapu, ikan nila, ikan gurami, ikan bandeng, ikan patin, ikan hias dan abalone. Program ini diharapkan dapat memberi kontibusi yang signifikan terhadap pertumbuhan ekonomi, perolehan devisa, penciptaan lapangan kerja dan peningkatan pendapatan pembudidaya. Kenyataan di lapangan, khusus untuk lele dumbo akhirakhir ini kualitasnya semakin menurun, berupa penurunan bobot per satuan waktu pemeliharaan, penurunan ketahanan terhadap penyakit, sehingga perlu ada inovasi untuk menjawab masalah ini.

Salah satu inovasi yang dapat menanggulangi masalah ini yaitu dengan probiotik. Probiotik didefinisikan sebagai mikroba hidup yang memiliki kemampuan terapeutik pada manusia yang mengkonsumsi makanan atau minuman yang mengandung bakteri probiotik (Praja, 2011). Menurut Guarner, et al, 2008, probiotik adalah mikroba hidup yyang dapat diformulasikan ke dalam berbagai jenis produk, termasuk makanan, obat-obatan, dan suplemen makanan. Spesies Lactobacillus dan Bifidobacterium yang paling sering digunakan sebagai probiotik, namun spesies ragi Saccharomyces cerevisiae dan beberapa Escherichia coli dan Bacillus juga digunakan sebagai probiotik. Tujuan utama penggunaan probiotik (kultur tunggal atau multikultur), antara lain meningkatkan kualitas air dan dasar tambak, meningkatkan kesehatan udang dan sebagai agent hayati (biological control agents) untuk mengendalikan berbagai penyakit pada tambak. Probiotik adalah mikroorganisme hidup non phatogen yang diberikan pada hewan untuk perbaikan laju pertumbuhan, efesiensi konsumsi ransum dan kesehatan hewan. Selain itu dijelaskan bahwa probiotik adalah feed additive berupa mikroba hidup menguntungkan yang mempengaruhi induk semang melalui perbaikan keseimbangan mikroorganisme dalam saluran pencernaan.

Probiotik dapat berupa satu atau beberapa jenis mikroorganisme (mikroorganisme tunggal atau kultur campuran). Bakteri Asam Laktat (BAL) merupakan salah satu kelompok bakteri yang banyak digunakan sebagai bakteri probiotik, akan tetapi tidak semua BAL termasuk sebagai bakteri probiotik. Bifidobacterium adalah salah satu genus Bakteri Asam Laktat (BAL) yang hidup dalam usus besar manusia. Beberapa karateristik dari bakteri ini adalah Gram-positif, anaerobik, tidak bergerak, tidak membentuk spora, berbentuk batang. Sel terlihat seperti huruf $\mathrm{V}$ atau $\mathrm{Y}$ karena berpasangan. Suhu optimal pertumbuhan sekitar $37-41^{\circ} \mathrm{C}$ dan $\mathrm{pH}$ optimum antara 6,5 - 7 (Praja, 2011).

Pemberian probiotik melalui lingkungan (air dan dasar tambak) bertujuan memperbaiki serta mempertahankan kualitas air dan dasar tambak, mengoksidasi senyawa 
organic sisa pakan, kotoran udang, plankton dan organisme mati, menurunkan senyawa metabolit beracun (ammonia, nitirt, $\mathrm{H}_{2} \mathrm{~S}$ ), mempercepat pembentukan dan kestabilan plankton, menurunkan pertumbuhan bakteri yang merugikan, penyedia pakan alami dalam bentuk flok bakteri dan menumbuhkan bakteri pengurai. Sedangkan pemberian bakteri melalui pakan bertujuan menyeimbangkan fungsi usus sehingga mampu menekan bakteri yang merugikan, menghasilkan enzim yang membantu sistem pencernaaan makanan, mengandung protin yang dapat dimanfaatkan oleh ikan dan udang yang memekannya, dan meningkatkan kekebalan tubuh udang dan ikan.

\section{METODE PELAKSANAAN}

Kegiatan ini merupakan salah satu kegiatan yang bergerak di bidang biologi. Tempat pelaksanaan pembuatan probiotik berada di desa Bening, kecamatan Gondang Mojokerto. Adapun sasaran dari kegiatan ini adalah peternak sapi di desa Bening melalui perbaikan pakan dengan membuat produk probiotik sendiri. Pada pembuatan probiotik dibutuhkan waktu selama 3 minggu tergantung cuaca untuk fermentasi.

Metode yang digunakan yaitu observasi yang dilakukan melalui pendekatan sosial ekonomi pada masyarakat sekaligus melakukan pemetaan peternakan di desa Bening. Sosialisasi yang dilakukan di hadiri oleh 5 orang peternak sapi dengan menjelaskan alat bahan dan langkah kerjapada saat pembuatan atau memperbanyak produk probiotik.

\section{ALAT BAHAN DAN LANGKAH KERJA}

Alat :

1. Paralon

2. Tong ukuran $30 \mathrm{~L}$

3. Lem paralon

4. Gergaji

5. Selang

6. Kayu pengaduk

7. Terpal

8. Jerami

Bahan :

1. Stater probiotik

2. Tetes tebu

3. Cacing sutra
4. Nanas (buah mengandung vitamin C)

5. Susu bubuk

6. Air kelapa

7. NPK, SPG36, PHONSKA

8. Air

\section{Persiapan Probiotik}

Menyiapkan alat dan bahan yang sudah disesuaikan.Melakukan sterilisasi pada wadah berbentuk drum untuk digunakan sebagai tempat penyimpanan probiotik. Wadah berbentuk drum diberi pipa untuk dieratkan dengan selang.

Langkah Kerja :

1. Menyiapkn semua alat dan bahan yang akan digunakan.

2. Kupas nanas, potong dadu kemudian diblender dan ditambahkan sedikit air.

3. Blender cacing sutra dan ditambahkan sedikit air.

4. Masukkan nanas dan cacing sutra yang sudah diblender, air kelapa dalam panci.

5. Masak (pasteurisasi) dengan suhu $70-75^{\circ} \mathrm{C}$ selama 15 menit.

6. Angkat dan masukkan dalam tong tutup tong agar udara (bakteri) diluar tong tidak masuk dalam tong.

7. Masukkan tetes tebu dalam panci. Masak (pasteurisasi) dengan suhu $70-75^{\circ} \mathrm{C}$ selama 15 menit.

8. Angkat dan masukkan dalam tong, masukkan susu bubuk aduk hingga rata kemudian tutup tong agar udara (bakteri) diluar tong tidak masuk dalam tong.

9. Buka tutup tong tambahkan air, beri rongga udara sekitar $10-$ $15 \mathrm{~cm}$ dari permukaan tutup tong.

10. Tutup kembali dan diamkan sampai dingin.

11. Pada ujung selang pembuangan udara pada tutup direndam dalam air agar udara luar tidak masuk. 
12. Setelah dingin masukkan stater probiotik, aduk rata dan tutup kembali.

13. Lapisi tong dengan jerami yang diletakkan diatas terpal dan bungkus tong dengan jerami agar susu didalam tong tetap stabil.

14. Fermentasi selama 3 minggu.

Manfaat probioti yaitu, menurunkanekanan darah, memperbaiki fungsi imun, mencegah infeksi, mengurangi inflamasi, meningkatkan penyerapan mineral dan mengurangi kekakacauan intestin dan sintesis nutrien.

\section{Aplikasi Probiotik}

Sebanyak 100 ekor untuk ternak atau budidaya ikan yaitu 2,5 $\mathrm{kg}$ pakan ditambahkan $10 \mathrm{ml}$ (1 tutup botol) probiotik, $10 \mathrm{ml}$ tetes, $500 \mathrm{ml}$ air kemudian dikocok hingga homogen dan simpan selama 3 hari, setelah 3 hari kemudian disemprotkan ke pakan. Apabila diberikan di kolom air yang aerobik sebaiknya diencerkan dulu dengan air tambak, kemudian ditebar merata (untuk perbaikan kualitas air). Sedangkan apabila diberikan di dasar tambak, penggunaannya dicampur dengan subtrat pembawanya misal dengan zeolit, caranya tuang zeolit ke dalam bak plastik campur dengan probiotik, aduk hingga merata dan tebarkan campuran tersebut di tambak terutama dibagian yang banyak endapan lumpur.

\section{HASIL DAN PEMBAHASAN}

Hasil kegiatan KKN-PPM yang telah dilakukan pada tanggal 06 februari 2018 dan di fermentasi hingga tanggal 28 februari 2018 di posyandu Desa Bening dan dilakukan sosialisasi pada tanggal 18 februari 2018 dengan warga desa bening, peserta sosialisasi sangat antusias dan sangat ingin melihat hasil dari produk probiotik ini karena di Desa Bening ini sebelumnya belum pernah mengetahui cara pembuatan probiotik dan bagaimana hasil nyata dari produk probiotik ini.

Hasil yang diperoleh mulai digunakan setelah bau harum seperti tape keluar dari cairan dan terdapat gelembung gas. Probiotik yang diencerkan atau diperbanyak di sini dari jenis probiotik yang dicampurkan ke dalam pakan. Sebelum digunakan, probiotik baru ini juga perlu diencerkan dulu dengan air. Volume yang digunakan lebih banyak dari volume saat digunakan probiotik aslinya.Selain menambah volume cairan probiotik hingga dapat digunakan lebih lama, penambahan tetes pada probiotik ini juga dimaksudkan untuk meningkatkan aktivitas bakteri yang ada di dalamnya. Dari pengamatan pemberian probiotik langsung dari botol dan probiotik yang telah dicampur dengan tetes ini pada bahan-bahan organik untuk keperluan fermentasi, terlihat probiotik yang hasil perbanyakan volume ini lebih cepat bereaksi pada bahan organik yang dicoba.

Pada bahan organik yang diberikan probiotik yang telah diencerkan, pemunculan gelembung gas dan bau fermentasinya lebih banyak dan lebih cepat terjadi dibandingkan saat digunakan probiotik originalnya. Untuk membuktikan probiotik yang dibuat berhasil atau tidak dengan cara pembuktian sederhana yaitu mengambil beberapa mililiter probiotik kemudian masukkan dalam botol dan mencampurnya dengan tetes atau gula kemudian tutup rapat tunggu hingga 24 jam. Apabila dalam 24 jam botol terdapat tekanan gas,maka probiotik berhasil. Tetapi hal yang terjadi adalah kebalikannya yaitu tidak terdapat gas ketika dibuka maka dapat di ambil hasil bahwa probiotik yang dibuat kali ini tidak berhasil karena terdapat faktor yang menjadi penyebap gagalnya pembuatan probiotik ini, faktor tersebut adalah: suhu di Desa Bening tidak sesuai dengan yang di butuhkan dalam pembuatan probiotik.

\section{KESIMPULAN}

Hasil kegiatan KKN-PPM program probiotik di Desa Bening Kecamatan Gondang Kabupaten Mojokerto untuk membantu peternak sapi sudah berhasil dilakukan terbukti pada pembuktian sederhana dalam botol terdapat tekanan gas. Dengan pemanfaatan pembuatan produk probiotik sendiri dapat mengurangi biaya pakan dan perawatan untk meningkatkan produktivitas ternak. Produk probiotik dapat meningkatkan pertambahan bobot badan dan mengifiensi pakan. 


\section{REFERENSI}

Endang, Jariah. 2013. Pengaruh Penambahan Probiotik pada Pakan dengan Dosis Berbeda terhdap Pertumbuhan, Kelulusidupan, Efisiensi Pakan dan Retensi Protein Ikn Patin (Pangasius hypopthalmus). http://jurnal.fp.unila.ac.id/index.p $\mathrm{hp} / \mathrm{bdpi} /$ article/view/119/124. Diakses tanggal 5 Maret 2018

Galeri UKM. 2010. Mempercepat Pertumbuhan Ikan Budidaya Dengan Probiotik.. Tersedia: http://galeriukm.web.id/unitusaha/perikanan/mempercepatpertumbuhan-ikan-budi-dayadengan-probiotik.

Diakses tanggal 27 Februari 2018

Kompiang IP. 2009. Pemanfaatan Mikroorganisme sebagai Probiotik untuk Meningkatkan produksi trnak Unggas di Indonesia. Jurnal Pengembangan Inovasi Pertanian 2 (3), 177-191
Mulyadi, A E. 2011. Pengaruh Pemberian Probiotik Pada Pakan Komersil Terhadap Laju Pertumbuhan Benih Ikan Patin Siam (Pangasius hypophthalamus). Skripsi. Fakultas Perikanan dan Ilmu Kelautan. Unpad: Jatinangor.

Praja, D.I. 2011. The Miracle of Probiotics. DIVA Press. Yogyakarta.

Reza, Rizky Filmi. 2011. Pengertian dan Klasifikasi Probiotik. Rizkyfilmi.blospot.co.id/2011/04/ artikel-probiotik.html?m=1. Diakses pada 10 Maret 2018.

Rostini, I. 2007. Peranan Bakteri Asam Laktat (LactobacillusPlantarum) Terhadap Masa Simpan Filet Nila Merah Pada Suhu Rendah. Fakultas Perikanan dan Ilmu Kelautan. Unpad:Jatinangor.

Sunarma, A. 2004. Peningkatan Produktifitas Usaha Lele Sangkuriang (Clarias sp.). Balai Budidaya Air Tawar Sukabumi: JawaBarat 